\title{
RNA-binding activity of translation initiation factor elF4G1 from Saccharomyces cerevisiae
}

\author{
CATHERINE BERSET, ${ }^{1}$ ANDREAS ZURBRIGGEN, SIAMAK DJAFARZADEH, MICHAEL ALTMANN, and \\ HANS TRACHSEL \\ Institute for Biochemistry and Molecular Biology, University of Berne, $\mathrm{CH}-3012$ Bern, Switzerland
}

\begin{abstract}
We identified and mapped RNA-binding sites of yeast Saccharomyces cerevisiae translation initiation factor elF4G1 and examined their importance for elF4G1 function in vitro and in vivo. Yeast elF4G1 binds to single-stranded RNA with three different sites, the regions of amino acids 1-82 ( $\mathrm{N}$ terminus), 492-539 (middle), and 883-952 (C terminus). The middle and C-terminal RNA-binding sites represent RS (arginine and serine)-rich domains; the N-terminal site is asparagine-, glutamine- and glycine-rich. The three RNA-binding sites have similar affinity for single-stranded RNA, whereas the affinity for single-stranded RNA full-length elF4G1 is about 100-fold higher (approximate $K_{d}$ of $5 \times 10^{-8} \mathrm{M}$ ). Replacement of the arginine residues in the middle RS site by alanine residues abolishes its RNA-binding activity. Deletion of individual RNA-binding sites shows that elF4G1 molecules lacking one binding site are still active in supporting growth of yeast cells and translation in vitro, whereas eIF4G1 molecules lacking two or all three RNA-binding sites are strongly impaired or inactive. These data suggest that RNA-binding activity is required for elF4G1 function.
\end{abstract}

Keywords: Cell-free translation; initiation of translation; RNA binding; RS domain; yeast

\section{INTRODUCTION}

Initiation of translation of most eukaryotic mRNAs involves recognition of the cap structure $\mathrm{m}^{7} \mathrm{GpppN}$ (where $\mathrm{N}$ is any nucleotide and $\mathrm{m}$ is a methyl group) at the $5^{\prime}$ end by the cap-binding protein eukaryotic Initiation Factor 4E (eIF4E) bound to the anchor protein eIF4G (for reviews, see Sachs et al. 1997; Gingras et al. 1999), recruitment of eIF4A and eIF4B, melting of RNA secondary structure close to the cap structure, binding of the $40 \mathrm{~S}$ ribosomal subunit and associated initiation factors ( $43 \mathrm{~S}$ initiation complex) to the $5^{\prime}$ end of the mRNA, and scanning of the mRNA in the $3^{\prime}$ direction by the $43 \mathrm{~S}$ initiation complex for the AUG initiation codon (Kozak 1989). AUG recognition leads to hydro-

Reprint requests to: Hans Trachsel, Institute for Biochemistry and Molecular Biology, University of Berne, Bühlstrasse 28, CH-3012 Bern, Switzerland; e-mail: hans.trachsel@mci.unibe.ch.

Present address: ${ }^{1}$ ESBATech, Wagistrasse 21, 8952 Schlieren, Switzerland.

Abbreviations: 5-FOA, fluoro-orotic acid; Ac, acetate; eIF, eukaryotic initiation factor; EMC, encephalomyocarditis; FPLC, fast performance liquid chromatography; GSH, glutathione; GST, glutathione-S-transferase; IRES, internal ribosome entry site; PBS, phosphate-buffered saline; SDS, sodium dodecyl sulfate; TBS, tris-buffered saline; UTR, untranslated region.

Article and publication are at http://www.rnajournal.org/cgi/doi/ 10.1261/rna.5380903. lysis of GTP bound to eIF2 in the initiation complex, release of initiation factors from the $40 \mathrm{~S}$ ribosomal subunit, and binding of a 605 ribosomal subunit to form an 80 S initiation complex competent to translate the open reading frame of the mRNA (for reviews, see Pain 1996; Hershey and Merrick 2000; Dever 2002).

Initiation factor eIF4G plays a central role in mRNA binding to the $40 \mathrm{~S}$ ribosomal subunit in the cap structure dependent initiation pathway. Mammalian eIF4G1 and its homolog, eIF4G2, contain domains interacting with eIF4E, eIF4A, eIF3, poly(A)-binding protein (Pabp1), and the kinase MNK1 (Lamphear et al. 1995; Mader et al. 1995; Imataka and Sonenberg 1997; Gradi et al. 1998; Imataka et al. 1998; Pyronnet et al. 1999). The RNA helicase eIF4A associated with eIF4G unwinds RNA secondary structure in the vicinity of the cap structure. This reaction is dependent on ATP and ATP hydrolysis and is stimulated by eIF4B. Interaction of eIF4G with the multisubunit factor eIF3 bound to the $40 \mathrm{~S}$ ribosomal subunit then promotes binding of the $43 \mathrm{~S}$ preinitiation complex to the $5^{\prime}$ end of the mRNA (for reviews, see Hentze 1997; Morley et al. 1997). In accordance with its important function in initiation of translation, the assembly of the multiprotein complex at the $5^{\prime}$ end of mRNA is regulated by intra- and extracellular signals through modulation of the interaction between eIF4E and 
eIF4G via eIF4E-binding proteins (for a review, see Gingras et al. 2001).

The Saccharomyces cerevisiae homologs of mammalian eIF4G1 and eIF4G2, yeast eIF4G1 and eIF4G2, are encoded by the genes TIF4631 and TIF4632 (Goyer et al. 1993) and are $50 \%$ identical at the amino acid level. Yeast cells with a disrupted TIF4631 gene display a slow growth phenotype (Lanker et al. 1992), whereas a double TIF4631 and TIF4632 gene disruption is lethal for yeast cells (Goyer et al. 1993). Like mammalian eIF4G, yeast eIF4G has been shown to interact with eIF4E (Mader et al. 1995; Altmann et al. 1997), eIF4A (Dominguez et al. 1999, 2001; Neff and Sachs 1999), and Pabp1, when the latter is bound to poly(A) (Tarun and Sachs 1996).

Besides interacting indirectly with the $5^{\prime}$ end of mRNA through eIF4E and with the $3^{\prime}$ end through Pabp1, eIF4G may also interact directly with mRNA or ribosomal RNA sequences. Indeed, a nucleic-acid-binding domain was found in wheat eIFiso4G (Kim et al. 1999). Furthermore, putative RNA-binding motifs were identified in yeast eIF4G by amino acid sequence inspection (Goyer et al. 1993). Originally, candidate sequences included a putative $\underline{R} N$ recognition motif (RRM) (amino acids 646-776) and two arginine- and serine-rich (RS) domains (amino acids 488553 and 873-908). RS domains consist of repeated arginine-serine dipeptides (and often contain additional repeats) and may be involved in protein-protein binding or mediate protein-nucleic acid interactions (Birney et al. 1993). RS domains are highly basic and therefore believed to interact with the negatively charged phosphate backbone of nucleic acids (Birney et al. 1993). Arginine residues contribute significantly to the interaction of RS domains with RNA, as they can form a network of hydrogen bonds with the sugar-phosphate backbone and the bases of RNA (Burd and Dreyfuss 1994).

The domain of yeast eIF4G containing the putative RRM (Goyer et al. 1993) was more recently shown to represent the eIF4A-binding site (Dominguez et al. 1999; Neff and Sachs 1999) and the homologous domain in mammalian eIF4G2, apart from interacting with eIF4A (Lamphear et al. 1995), was demonstrated to bind to the internal ribosome entry site (IRES) of EMC viral RNA (Pestova et al. 1996). Structural analysis revealed that this domain folds like a HEAT repeat (five antiparallel pairs of $\alpha$-helices) and not like an RRM (Marcotrigiano et al. 2001). Because the region containing the HEAT repeat is well conserved between mammalian and yeast eIF4G at the amino acid level (Marcotrigiano et al. 2001) and serves as a binding site for both yeast and mammalian eIF4A (Dominguez et al. 2001), we assume that yeast eIF4G also contains a HEAT repeat.

In this work, we mapped RNA-binding sites on eIF4G1 and examined the importance of RNA-binding activity of eIF4G1 for translation in vitro and growth of yeast cells.

\section{RESULTS}

\section{Identification of RNA-binding sites of elF4G1}

The role played by eIF4G in initiation of translation very likely requires its direct interaction with mRNA and/or ribosomal RNA. To test full-length eIF4G1 and parts of the protein for RNA-binding activity, we expressed different fragments as glutathione S-transferase (GST) fusion proteins in Escherichia coli, isolated the fusion proteins by glutathione S-Sepharose affinity chromatography, cleaved the GST part from the hybrid proteins with protease, and purified the eIF4G1 moiety by fast performance liquid chromatography (FPLC) chromatography. Most of the fragments were subcloned using in-frame BglII restriction sites (see Materials and Methods; Fig. 1A). The purified recombinant proteins are shown in Figure 1B. We could not obtain homogenous full-length eIF4G1 protein but were able to reduce the amount of degradation products by coexpressing eIF4E (Fig. 1B, lane 2). The predicted molecular weight of yeast eIF4G1 is $107 \mathrm{kD}$, but the protein migrates much slower on sodium dodecyl sulphate (SDS) polyacrylamide gels (Goyer et al. 1993). The smaller band of the doublet represents eIF4G1 $1_{1-456}$ as determined by mass analysis (results not shown). This fragment migrates aberrantly and was shown earlier to be inactive in eIF4A binding (Dominguez et al. 2001). Because its C terminus lies in the eIF4E-binding site, this fragment is expected not to bind eIF4E. We do not know whether eIF4G1 $1_{1-456}$ is generated by proteolysis or premature termination of translation in $E$. coli. Because the fusion protein eIF4G1 $1_{160-492}$ (predicted molecular weight of $66 \mathrm{kD}$ ) also migrates slower than expected on SDS gels at about $100 \mathrm{kD}$ (Fig. 1B, lane 3), sequences responsible for aberrant migration of eIF4G1 must be located in this region. Interestingly, abnormal migration of eIF4G on SDS gels was also observed for mammalian eIF4G and was shown to be due to the N-terminal domain of the protein (Yan et al. 1992; Lamphear et al. 1995). Other fragments of eIF4G1 migrate as expected: eIF4G1 $1_{592-862}$ at about $30 \mathrm{kD}$ (Fig. 1B, lane 5), eIF4G1 $1_{883-952}$ at about $8 \mathrm{kD}$ (Fig. 1B, lane 6), eIF4G1 $1_{492-539}$ at about $6 \mathrm{kD}$ (Fig. 1B, lane 7) and eIF4G1 $1_{1-82}$ at about $9 \mathrm{kD}$ (Fig. 1B, lane 8). As a negative control in RNA-binding assays, GST was expressed from the vector $\mathrm{pGEX}-1 \lambda \mathrm{T}$ and purified on glutathione S-Sepharose (not shown).

To test for RNA-binding activity of eIF4G1 and eIF4G1 fragments, we first used a filter-binding assay. Proteins were incubated with radioactively labeled single-stranded RNA and the reaction mixtures passed through nitrocellulose membranes (which retain protein). Radioactivity retained on the filters after washing represents RNA bound to protein. Typical titration curves for three of the proteins are shown in Figure 1C. We cleaved the GST moiety from the fusion proteins for these experiments; however, control experiments showed that GST fusion proteins behave identi- 
A

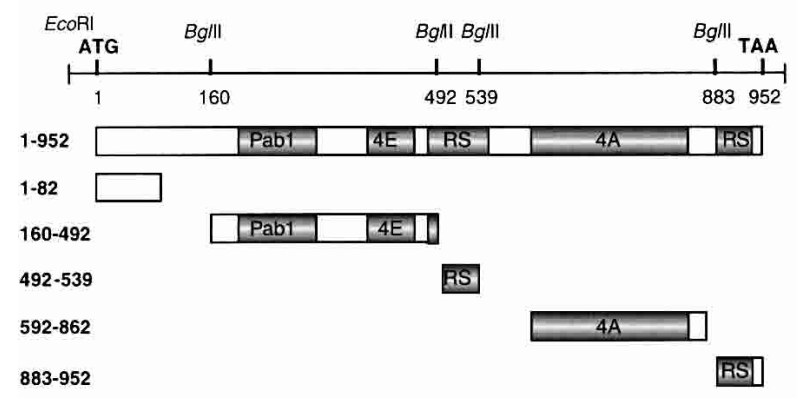

C

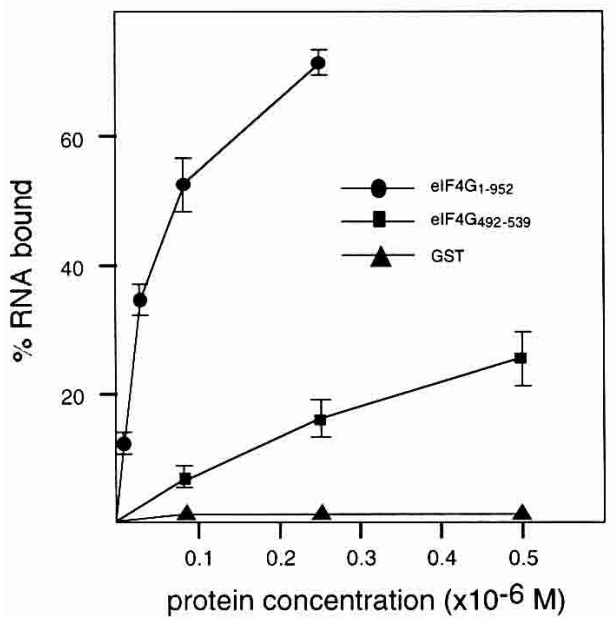

B

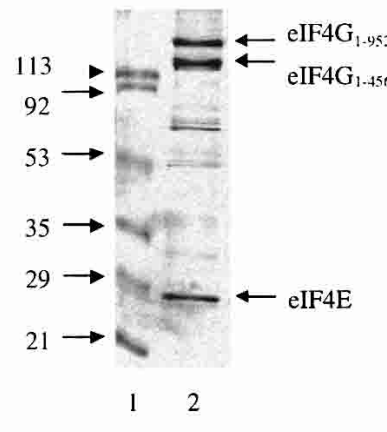

KDapprox (M)

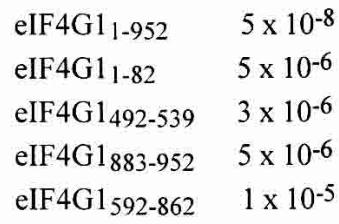

FIGURE 1. Identification of eIF4G1 RNA-binding sites. (A) Schematic representation of yeast eIF4G1 and eIF4G1 fragments. The DNA with the relevant restriction sites used for subcloning is shown on top. ATG and TAA indicate start and end of the open reading frame. The numbers indicate amino acid positions. Pab1, poly(A)-binding protein 1 binding domain; 4E, eIF4E-binding domain; RS, arginine- and serine-rich domain; 4A, eIF4A-binding domain. (B) About 1-2 $\mu$ g of each protein were fractionated on 15\% (lanes 1-3) and 20\% (lanes 4-8) SDS polyacrylamide gels and stained with Coomassie blue. (Lanes 1,4) molecular weight markers (numbers indicate kilodaltons), (lane 2) eIF4G1 $1_{1-952}$, (lane 3) eIF4G1 $160-492$, (lane 5) eIF4G1 ${ }_{592-862}$, (lane 6) eIF4G1 ${ }_{883-952}$, (lane 7) eIF4G1 ${ }_{492-539}$, (lane 8) eIF4G1 $1_{1-82}$. (C) Filter-binding assay. On the left, the titration curves of three of the proteins are shown. Proteins were titrated with 0.25 pmole $\left[{ }^{32} \mathrm{P}\right]$-labeled 38 -nt RNA in a 20 - $\mu \mathrm{L}$ reaction volume containing buffer A. On the right, $K_{\text {Dapprox. }}$ values for eIF4G1 proteins are shown. For estimation of protein concentration of full-length eIF4G1, only the slowest migrating band ( $B$, lane 3 ) was included.

cally in RNA-binding experiments. Full-length eIF4G1 $1_{1-952}$ showed the highest affinity for RNA with an estimated $K_{D}$ $\left(K_{\text {Dapprox. }}\right)$ of $5 \times 10^{-8} \mathrm{M}$ whereas the fragments eIF4G1 $1-82$, eIF4G1 $1_{492-539}$, and eIF4G1 ${ }_{883-952}$ show about 100 -fold lower affinity. The fragments eIF4G1 $1_{160-492}$, eIF4G1 $1_{542-883}$ (not shown), and eIF4G1 $1_{592-862}$, as well as GST (used as negative control) did not bind significant amounts of RNA. The presence of eIF4E in full-length eIF4G1 had no effect on RNA-binding activity as eIF4G1 expressed in its absence has the same affinity for RNA (result not shown).

We can exclude RNA degradation as the cause for low RNA-binding activity, because we checked the integrity of RNA after incubation by fractionating incubation mixtures on denaturing urea gels and exposing gels to X-ray film. A major band migrating at the position of intact RNA was observed after incubation, indicating little or no degradation of RNA in the filter-binding assay. Proteins that bind RNA with high affinity might retain bacterial RNA during their purification from E. coli; however, none of the purified proteins shown in Figure 1B carried nucleic acids, as revealed by UV light absorption at 260 and $280 \mathrm{~nm}$.

We verified the RNA-binding activity of eIF4G1 and eIF4G1 fragments by a different method and chose adsorption to $\operatorname{poly}(\mathrm{U})$-agarose (Kim et al. 1999), which has the advantage over the filter-binding assay of allowing visualization of proteins bound to RNA. We tested full-length eIF4G1 $1_{1-952}$ and the fragments eIF4G1 $1_{1-82}$, eIF4G1 $1_{492-539}$, and eIF4G1 $1_{883-952}$ carrying RNA-binding sites as determined by filter-binding assays. The fragments eIF4G1 $1_{542-883}$ and a shorter version, eIF4G1 $1_{592-862}$, which lacks the last few arginine and serine residues of the middle RS domain, were used as negative controls. To test whether arginines in the RS domains are involved in RNA binding, we also analyzed the fragment eIF4G1 $1_{492-539 / 12 \mathrm{R} \rightarrow \mathrm{A}}$ with all 12 arginine residues replaced by alanine residues (Fig. 2). We used GST fusion proteins in this experiment but obtained 


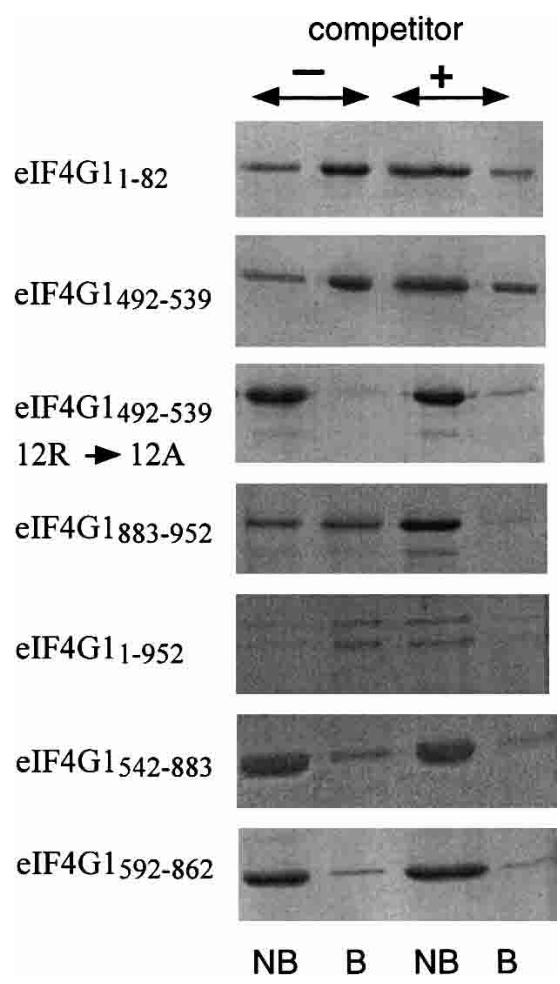

FIGURE 2. Binding of eIF4G1 and eIF4G1 fragments to poly(U) agarose. Purified GST-eIF4G1 fusion proteins were bound to poly(U) agarose for $30 \mathrm{~min}$ at $4^{\circ} \mathrm{C}$, the resin washed extensively with buffer, proteins bound to the matrix eluted by boiling with SDS sample buffer, fractionated on $17.5 \%$ SDS polyacrylamide gels, and stained with Coomassie blue. Where indicated, the protein was preincubated for $15 \mathrm{~min}$ with soluble poly(U). For each fusion protein, unbound protein $(\mathrm{NB})$ and protein bound to the matrix (B) in the absence (first and second lanes) and in the presence (third and fourth lanes) of soluble $\operatorname{poly}(\mathrm{U})$ is shown.

the same results with cleaved proteins. Specific binding to the $\operatorname{poly}(\mathrm{U})$ part of $\operatorname{poly}(\mathrm{U})$-agarose was verified by competition of binding with excess free poly(U). All three eIF4G1 fragments carrying RNA-binding sites as determined in the filter-binding assay as well as full-length eIF4G1 bound to poly(U)-agarose and binding is competed by free $\operatorname{poly}(\mathrm{U})$. The full-length preparation of eIF4G1 used for these experiments also contained the fragment eIF4G1 $1_{1-456}$. This fragment contained the N-terminal RNAbinding site and bound to poly $(\mathrm{U})$-agarose. In contrast, the binding of eIF4G1 $1_{542-883}$ and eIF4G1 $1_{592-862}$ to poly(U)-agarose was very low and not influenced by free poly $(\mathrm{U})$. The same was true for eIF4G1 ${ }_{492-539 / 12 \mathrm{R} \rightarrow \mathrm{A}}$, supporting the hypothesis that arginine residues contribute to the ability of the protein to bind to RNA.

We conclude from these results that eIF4G1 contains at least three sites, amino acids 1-82, 492-539, and 883-952, able to interact with RNA. The two latter sites correspond to the arginine- and serine-rich regions originally identified as candidate RNA-binding sites by inspection of the eIF4G1 amino acid sequence (Goyer et al. 1993).

\section{RNA-binding sites of eIF4G1 are required for growth of yeast cells}

To test whether regions of eIF4G1 identified as RNA-binding sites are required for growth, we expressed eIF4G1 proteins containing deletions of single or multiple RNA-binding sites in yeast cells with disrupted TIF4631 and TIF4632 genes (see Materials and Methods). The mutants $\Delta 1$ [deletion of amino acids (aa) 1-186], $\Delta 2$ (deletion of aa 492539), $\Delta 3$ (deletion of aa 844-952), combinations of two or three deletions $(\Delta 1 \Delta 2, \Delta 1 \Delta 3, \Delta 2 \Delta 3, \Delta 1 \Delta 2 \Delta 3)$, and combinations of deletions of $\mathrm{N}$ - and $\mathrm{C}$-terminal sites with $\mathrm{mu}$ tations of arginines to alanines in the middle domain $(\Delta 1 \mathrm{~m} 2 \Delta 3)$ were expressed either from the galactose inducible GAL1/10 promoter or from the eIF4G promoter, and we tested whether they could replace wild-type eIF4G1 in supporting growth of cells (Fig. 3). Deletion of all three RNA-binding sites $(\Delta 1 \Delta 2 \Delta 3)$, deletion of the $\mathrm{N}$ - and Cterminal RNA-binding sites, and replacement of arginine residues by alanines in the remaining middle RNA-binding site $(\Delta 1 \mathrm{~m} 2 \Delta 3)$ or deletion of both the middle and C-terminal RNA-binding sites $(\Delta 2 \Delta 3)$ were lethal for yeast cells (Fig. 3B). eIF4G1 molecules missing one of the RNA-binding sites $(\Delta 1, \Delta 2$, or $\Delta 3)$ supported growth. Deletion of the C-terminal RNA-binding site $(\Delta 3)$ led to a temperaturesensitive (ts) phenotype, deletion of the $\mathrm{N}$-terminal domain $(\Delta 1)$ conferred a ts phenotype only when expressed from the GAL1/10 promoter, and deletion of the middle RNAbinding site $(\Delta 2)$ produced no visible phenotype. Mutant eIF4G1 with both the $\mathrm{N}$ - and C-terminal RNA-binding sites deleted $(\Delta 1 \Delta 3)$ was still able to support growth of cells but conferred a ts phenotype, whereas $\Delta 1 \Delta 2$ was lethal when expressed from the eIF4G promoter but partially functional (ts) when expressed from the GAL1/10 promoter. The different phenotypes of $\Delta 2$ and $\Delta 1 \Delta 2$ when expressed from either the GAL1/10 or eIF4G promoter might reflect differences in expression levels.

To test whether lethal phenotypes might be due to lack of expression of the corresponding proteins, their expression from the GAL1/10 promoter and from eIF4G1 promoter in cells coexpressing wild-type eIF4G1 from its own promoter was analyzed by Western blotting. The expression of the nonlethal mutant proteins was also analyzed after FOA selection (results not shown). All mutant eIF4G1 proteins could be detected at similar or somewhat reduced levels (compared to wild-type eIF4G1) except $\Delta 1 \Delta 2$ and $\Delta 1 \Delta 2 \Delta 3$ expressed from the eIF4G1 promoter, which were not detected. We conclude that $\Delta 1 \Delta 2 \Delta 3$ is a nonfunctional protein, as expression from the GAL1/10 promoter leads to lethal phenotype whereas $\Delta 1 \Delta 2$ is still partially active and the lethal phenotype (when expressed from the eIF4G1 promoter) due to lack of or too low expression.

These results suggest that RNA-binding sites of eIF4G1 are essential for growth. Deletion of all three RNA-binding sites $(\Delta 1 \Delta 2 \Delta 3)$ inactivates eIF4G1. Deletion of two RNA- 
A

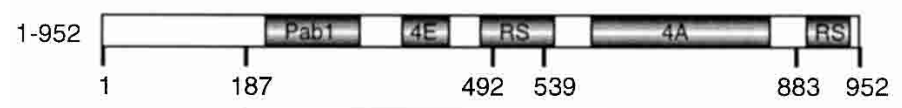

$\begin{array}{lll}41 & \end{array}$

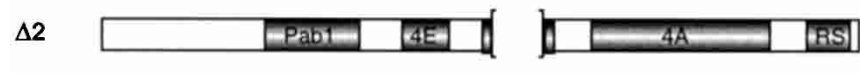

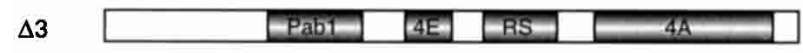

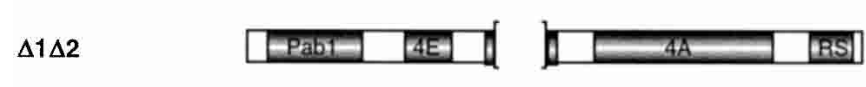

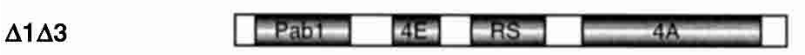
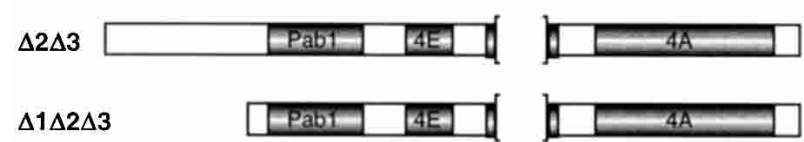

$\Delta 1 \mathrm{~m} 2 \Delta 3$

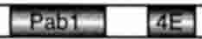

B

\begin{tabular}{|l|c|c|}
\hline & \multicolumn{2}{|c|}{ growth } \\
\hline eIF4G & Gal promoter & eIF4G promoter \\
\hline eIF4G1 $1-952$ & wt & wt \\
\hline$\Delta 1$ & ts & wt \\
\hline$\Delta 2$ & wt & wt \\
\hline$\Delta 3$ & ts & ts \\
\hline$\Delta 1 \Delta 2$ & ts & lethal \\
\hline$\Delta 1 \Delta 3$ & ts & ts \\
\hline$\Delta 2 \Delta 3$ & lethal & lethal \\
\hline$\Delta 1 \Delta 2 \Delta 3$ & lethal & lethal \\
\hline$\Delta 1 \mathrm{~m} 2 \Delta 3$ & lethal & lethal \\
\hline
\end{tabular}

FIGURE 3. In vivo phenotype of eIF4G1 deletion mutants. (A) Schematic representation of yeast eIF4G1 and eIF4G1 fragments. Pab1, poly(A) binding protein binding domain; 4E, eIF4E-binding domain; RS, arginine- and serine-rich domains; 4A, eIF4A-binding domain. (B) The phenotype observed on plates of yeast strains expressing the various eIF4G1 deletion proteins as only source of eIF4G1 (either under the Gal1/10 or the eIF4G promoter) is indicated. wt, wild-type growth; ts, temperature sensitive (no growth at $37^{\circ} \mathrm{C}$, normal growth at $30^{\circ} \mathrm{C}$ ).

binding sites inactivates eIF4G1 either fully $(\Delta 2 \Delta 3)$ or partially $(\Delta 1 \Delta 2$ and $\Delta 1 \Delta 3)$. Deletion of one RNA-binding site has either no effect $(\Delta 2)$ or leads to partial inactivation $(\Delta 1$, $\Delta 3)$. This suggests that at least one RNA-binding site (middle or C-terminal) is required and two RNA-binding sites are sufficient for eIF4G1 function in vivo.

\section{RNA-binding sites of elF4G1 are required for translation in vitro}

We next asked whether mutant eIF4G1 proteins lacking RNA-binding sites show a defect in supporting translation initiation in vitro. For these experiments we used an eIF4G-dependent yeast extract. This extract is inactive in translation due to two mutations in eIF4G1 that lead to loss of interaction of eIF4G1 with eIF4A (Dominguez et al. 2001). Addition of eIF4G1 restores translation of total yeast RNA as shown by the stimulation of methionine incorporation into protein. The eIF4G1 deletion mutants shown in Figure 3A were expressed as GST fusion proteins together with eIF4E in E. coli, proteins purified by affinity chromatography as described (see Materials and Methods) and tested in the eIF4G-dependent cell free translation system (Fig. 4). We had found earlier that the presence of eIF4E in eIF4G1 preparations does not measur- ably influence the activity of eIF4G1 in this in vitro translation system (Dominguez et al. 2001). A range of concentrations of each protein was measured to determine the optimal concentration for stimulation of translation. $\mathrm{Mu}-$ tant proteins with single deletions $\Delta 1$ and $\Delta 2$ were active in stimulating translation, whereas $\Delta 3$ and $\Delta 1 \Delta 3$ were only weakly active. The mutant proteins $\Delta 1 \Delta 2, \Delta 2 \Delta 3$, and $\Delta 1 \Delta 2 \Delta 3$ were inactive for in vitro translation. These data show that the requirements for individual RNA-binding

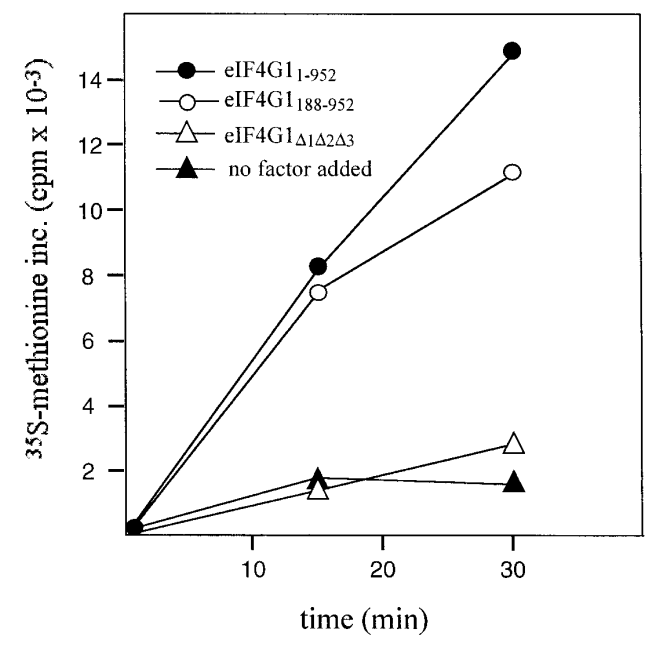

\begin{tabular}{|l|c|}
\hline \multicolumn{1}{|c|}{ eIF4G } & $\begin{array}{l}\text { stimulation of } \\
\text { translation in vitro }\end{array}$ \\
\hline eIF4G11-952 & ++ \\
\hline$\Delta 1$ & ++ \\
\hline$\Delta 2$ & ++ \\
\hline$\Delta 3$ & + \\
\hline$\Delta 1 \Delta 2$ & - \\
\hline$\Delta 1 \Delta 3$ & + \\
\hline$\Delta 2 \Delta 3$ & - \\
\hline$\Delta 1 \Delta 2 \Delta 3$ & - \\
\hline
\end{tabular}

FIGURE 4. In vitro translation of GST-eIF4G1 fusion proteins in an eIF4G-dependent extract. Methionine incorporation at $25^{\circ} \mathrm{C}$ was measured as described previously (Dominguez et al. 1999) using $10-\mu \mathrm{L}$ reaction mixtures containing $5 \mu \mathrm{g}$ total yeast RNA as mRNA source and 3.6 $\mu \mathrm{Ci}{ }^{35} \mathrm{~S}$-methionine. The kinetics of methionine incorporation for four proteins is shown on the left. On the right, stimulation of translation is indicated by ++ (like GST-eIF4G1 $1_{1-952}$ and GST-eIF4G1 $188-952)$; +, intermediate; -, like "no factor added." 
sites for growth of yeast cells and translation in vitro are qualitatively very similar.

We tested whether eIF4G1 deletion mutants inactive in translation initiation in vitro still interact with eIF4E and eIF4A. GST-eIF4G1 fusions proteins (coexpressed with eIF4E in E. coli) bound to glutathione-Sepharose were incubated with purified eIF4A, eluted by boiling with SDS sample buffer, fractionated on SDS gels, and analyzed by Western blotting, using antibodies against eIF4E, eIF4G, and eIF4A (Fig. 5). All purified mutant proteins bound to eIF4E and eIF4A, whereas GST did not interact with eIF4E or eIF4A (only the proteins inactive in in vitro translation are shown in Fig. 5). The eIF4A band in this experiment is not particularly strong but nontheless specific: Reaction of GST-eIF4G1 $1_{1-952}$ with anti-eIF4A antibody gave no signal (result not shown). This indicates that the mutant eIF4G1 proteins are correctly folded and capable of interacting with other initiation factors.

\section{RNA-binding activity of eIF4G1 deletion mutants}

To examine the effect of removing RNA-binding sites on overall RNA-binding activity of eIF4G1, deletion mutants were tested for RNA binding in vitro in the filter-binding assay and approximate $K_{D}$ values calculated (Fig. 6). Fulllength eIF4G1, $\Delta 1, \Delta 2, \Delta 3$, and $\Delta 1 \Delta 3$ bound RNA effi-

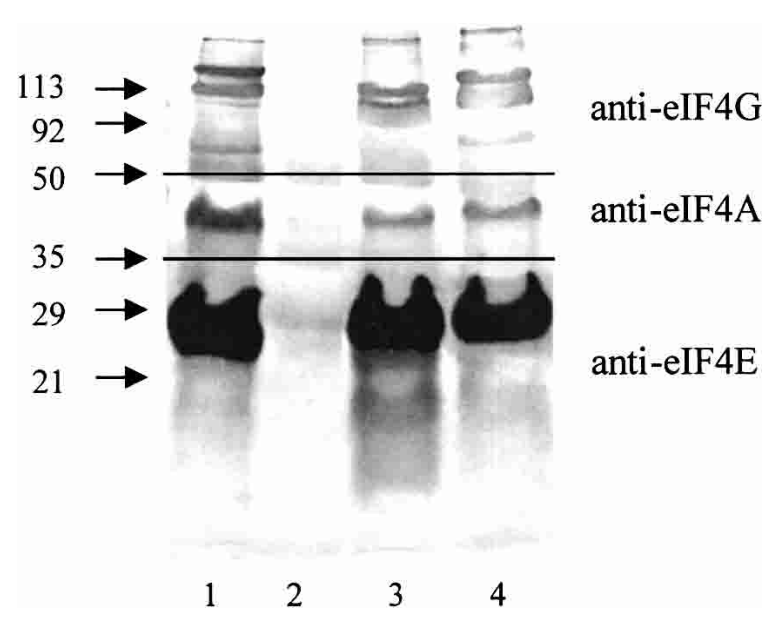

FIGURE 5. Interaction of GST-eIF4G1 proteins with eIF4E and eIF4A. Approximately 40 pmole of the eIF4G1 proteins (coexpressed with eIF4E in E. coli and purified on glutathione-Sepharose) were diluted to $1.5 \mathrm{~mL}$ in $\mathrm{TBS} / \mathrm{NaCl} / \mathrm{Triton}$ and bound on $20 \mu \mathrm{L}$ of glutathione-Sepharose for $2 \mathrm{~h}$ at $4^{\circ} \mathrm{C}$. The resin was washed twice with TBS and once with buffer A. The resin was resuspended in $100 \mu \mathrm{L}$ of buffer B, incubated with $0.2 \mu \mathrm{g}$ of purified eIF4A (expressed in E. coli) for 1 $\mathrm{h}$ at $4^{\circ} \mathrm{C}$, washed four times with buffer $\mathrm{B}$, and transferred into fresh Eppendorf tubes. Proteins bound were eluted by boiling with SDS sample buffer, fractionated on SDS polyacrylamide gels, and analyzed by Western blotting, using antibodies against eIF4E, eIF4G, and eIF4A as described (Berset et al. 1998). (Upper panel) anti-eIF4G antibody, (middle panel) anti-eIF4A antibody, (lower panel) anti-eIF4E antibody. (Lane 1) eIF4G1 $1-952$, (lane 2) GST, (lane 3) GST-eIF4G1 $\Delta 1 \Delta 2 \Delta 3$, (lane 4) GST-eIF4G1 $\Delta 1 \mathrm{~m} 2 \Delta 3$.

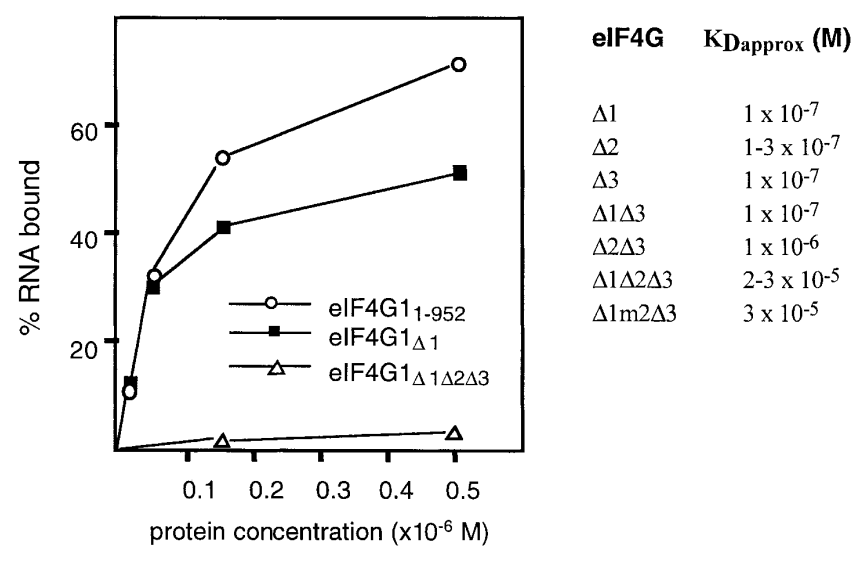

FIGURE 6. Filter-binding assay. The titration curves of three of the GST-eIF4G1 fusion proteins tested are shown on the left. Proteins were titrated against 0.25 pmole $\left[{ }^{32} \mathrm{P} \mid\right.$-labeled 38 -nt RNA in a $20-\mu \mathrm{L}$ reaction volume containing buffer A. $K_{\text {Dapprox. }}$ values for GST-eIF4G1 fusion proteins are shown on the right.

ciently $\left(K_{\text {Dapprox. }}\right.$ around $\left.1 \times 10^{-7} \mathrm{M}\right)$, whereas the mutant $\Delta 2 \Delta 3$ had a 10 -fold lower affinity for RNA and $\Delta 1 \Delta 2 \Delta 3$ and $\Delta 1 \mathrm{~m} 2 \Delta 3$ were strongly impaired in RNA binding ( $K_{\text {Dapprox. }}$ around $2-3 \times 10^{-5} \mathrm{M}$ ). We did not calculate the $K_{\text {Dapprox. }}$ for $\Delta 1 \Delta 2$ because this protein preparation contained fragments that made protein concentration determination and therefore $K_{\text {Dapprox. }}$ calculation unreliable.

We conclude from these data that RNA-binding activities and activities in translation initiation in vitro of the deletion proteins correlate well with RNA-binding activity, indicating that RNA-binding activity is required for eIF4G1 activity in vitro and in vivo.

\section{DISCUSSION}

In this work, we show that yeast eIF4G1 contains three RNA-binding sites. The N-terminal region of eIF4G1, amino acids 1-82, contains 12 glutamine, 12 asparagine, 10 glycine, 6 arginine, and 6 tyrosine residues. They are arranged as glycine cluster, RGG-, and RG-motifs. Glycinerich clusters are common in RNA-binding proteins and are composed of glycine-glycine dipeptides interspersed with arginine and aromatic residues (RGG or GAR domains; Birney et al. 1993). The RGG motif is ubiquitous in proteins involved in splicing or pre-rRNA processing, in RNA helicases, and hnRNPs (Ghisolfi et al. 1992; Kiledjian and Dreyfuss 1992; Birney et al. 1993). RNA-binding activity of the $\mathrm{N}$-terminal part of eIF4G1 is supported by amino acid sequence comparison with other proteins implicated in RNA binding. A search for related sequences revealed homology with Trypanosoma brucei nucleolar RNA-binding protein Nopp44/46 (TrEMBL, Q26711) (36\% identity in a 64 amino acid sequence), which also carries RGG motifs.

Full-length eIF4G2 shows similar RNA-binding activity like eIF4G1 (our unpubl. result). Even though we have not 
tested fragments of eIF4G2 for RNA-binding activity, we anticipate that eIF4G2 also contains three RNA-binding sites. The amino acid sequences of the middle and C-terminal arginine- and serine-rich RNA-binding sites are well conserved between eIF4G1 and eIF4G2, 62\% identity for eIF4G1 ${ }_{492-539}$ compared to eIF4G2 $2_{462-503}$ and $38 \%$ for eIF4G1 ${ }_{883-952}$ compared to eIF4G2 ${ }_{854-914}$ (sequence identity determined with the program Bestfit from the GCG-Wisconsin package). It is interesting to note that eIF4G1 ${ }_{492-539}$ is located close to the eIF4E-binding domain. It is possible that this RNA-binding site contributes to the stability of the complex formed by eIF4G, eIF4E (interacting with the cap structure of mRNA), and mRNA. The N-terminal parts of eIF4G1 and eIF4G2 are not very strongly conserved $(28 \%$ identity), but basic amino acid residues and asparagine residues are conserved in number and position.

The eIF4G1 fragment containing the putative HEAT repeat motif, eIF4G1 $1_{542-883}$, showed very low RNA-binding activity in our assay. Interestingly, the homologous domain in mammalian eIF4G binds to the IRES of EMC viral RNA (Pestova et al. 1996; Marcotrigiano et al. 2001) and this binding is strongly stimulated by eIF4A (Lomakin et al. 2000). Apparently, this domain recognizes specific RNA sequences. We tested whether the binding of eIF4A to eIF4G1 $1_{542-883}$ might enhance the affinity of eIF4G1 for RNA, perhaps through a change of conformation. However, eIF4A did not influence the RNA-binding activity of eIF4G1 $1_{542-883}$ or of full-length eIF4G1. Besides synthetic RNA, we also tested diverse in vitro transcribed RNAs for binding to our eIF4G1 preparations and did not observe significantly different affinities (results not shown). The questions of whether certain RNA sequences show different affinty for eIF4G and of whether eIF4G1 $1_{542-883}$ might bind certain sequences, perhaps IRES sequences, remain therefore open.

In the filter-binding assays, proteins carrying single RNAbinding sites (eIF4G1 $1_{1-82}$, eIF4G1 ${ }_{492-539}$, and eIF4G1 ${ }_{883-952}$ ) bound RNA with about 100-fold lower affinity than fulllength eIF4G1 protein. This difference may be due to binding of two or three domains to a single RNA molecule or a conformational change in the protein leading to enhanced affinity of individual RNA-binding sites.

In vivo, eIF4G1 mutants carrying two of the three RNAbinding sites were fully $(\Delta 1, \Delta 2)$ or partially functional $(\Delta 3)$, whereas proteins containing only one RNA-binding site were either nonfunctional $(\Delta 2 \Delta 3)$ or partially functional $(\Delta 1 \Delta 2, \Delta 1 \Delta 3)$. To support growth of yeast cells, eIF4G1 containing only the C-terminal RNA-binding site (mutant $\Delta 1 \Delta 2$ ) requires expression from the GAL1/10 promoter (presumably overexpression) and eIF4G1 containing only the middle RNA-binding site (mutant $\Delta 1 \Delta 3$ ) is unable to support growth at $37^{\circ} \mathrm{C}$. Mutant eIF4G1 proteins lacking all three RNA-binding sites $(\Delta 1 \Delta 2 \Delta 3)$ or eIF4G1 with Nand C-terminal RNA-binding sites deleted and argine residues in the remaining middle site replaced by alanine
$(\Delta 1 \mathrm{~m} 2 \Delta 3)$ are not functional. These data show that two RNA-binding sites in eIF4G1 (one of them being the Cterminal RNA-binding site) are required for normal growth of yeast cells.

In in vitro translation experiments, the activities of mutant eIF4G1 proteins closely resemble their activities in supporting growth of yeast cells. This correlation indicates that the inability of mutant eIF4G1 proteins to support growth is due to their inability to support translation initiation. The defect in translation initiation is not caused by a defect in binding to eIF4A or eIF4E (Fig. 5) but may be due to reduced ability to bind RNA. This view is supported by the correlation of RNA-binding activity of mutant proteins with their activities in supporting growth and translation initiation in vitro.

It remains to be elucidated whether RNA-binding sites of eIF4G1 bind messenger RNA and/or ribosomal RNA in vivo. Binding of eIF4G1 to the latter would contribute to the interaction between ribosomes and mRNA. With three distinct RNA-binding sites, eIF4G1 could bind to an mRNA molecule at several contact points simultaneously and bring it into a specific conformation to allow the binding of the 40 S ribosomal subunit.

\section{MATERIALS AND METHODS}

\section{Plasmid construction}

\section{Fragments of elF4G1}

GST fusion proteins were expressed in E. coli from the vectors pGEX-1 $\lambda$ T, pGEX-2T, or pGEX-6P-2 (Pharmacia Biotech). The complete TIF4631 open reading frame on a 3266-bp DNA EcoRI fragment was subcloned from the plasmid pCG8.4 (Goyer et al. 1993). eIF4G1 ${ }_{160-492}$, eIF4G1 ${ }_{492-539}$, and eIF4G1 $1_{542-883}$ were subcloned as BglII fragments into the BamHI site and eIF4G1 $1_{883-952}$ as $B g l \mathrm{II} / E c o$ RI fragment into the BamHI/EcoRI sites of pGEX-1 $\lambda \mathrm{T}$. The cDNA encoding eIF4G1 $1_{1-952}$ with six histidine residues at the carboxy terminus (introduced by PCR) was subcloned as EcoRI fragment into pGEX-6-P2 to obtain pGEX6-TIF4631. eIF4G1 $1_{592-863}$ and eIF4G1 $1_{863-952}$ were obtained by PCR amplification using primer pairs 5'-CCGGATCCCTAGCCCCTGACGGAAAGACC-3'; 5'-CCGAATTCTCACTTAGGACCGTTGTCCTTCT-3' and 5'CCGGATCCACCATTCAACAGATTCATGAGG-3'; and 5' -CCG AATTCTTACTCTTCGTCATCACTTTCTCC-3' and subcloning of the BamHI-EcoRI-digested DNA fragments into pGEX-6-P2.

eIF4G1 $1_{1-82}$ was obtained by exonuclease III treatment of pGEX6-TIF4631 (Henikoff 1987, 1990). Constructs were sequenced and transformed into the E. coli strain BL21 carrying a plasmid encoding a rare arginyl-tRNA and conferring chloramphenicol resistance (Saxena and Walker 1992).

\section{Deletion and mutation of RNA-binding sites}

The N-terminal deletion eIF4G1 $1_{187-952}(\Delta 1)$ was obtained by PCR amplification from TIF4631 DNA using the upstream primer 5' CCGGATCCATAATGCCACTAATGACTCTAAGGCC-3' (which introduces a new start ATG at amino acid position 186) and the 
downstream primer 5'-GAATTAGCTCTGTCATCC-3' and subcloning of the BamHI-HpaI fragment (a unique HpaI site is located at the site encoding amino acid 298 of TIF4631 DNA) into the unique sites of pGEX6-TIF4631. The C-terminal deletion eIF4G1 $1_{1-843}(\Delta 3)$ was obtained by exonuclease III treatment of pGEX6-TIF4631. The combined N-terminal and C-terminal deletion mutant eIF4G1 $1_{187-843}(\Delta 1 \Delta 3)$ was obtained by inserting the HpaI-EcoRI fragment of pGEX6-TIF4631/D844-952 into pGEX6TIF4631/ $\Delta 1-186$. The triple deletion mutant pGEX6-TIF4631 $\Delta 1-186 / \Delta 493-541 / \Delta 844-952$ was obtained by BglII digestion and religation of pGEX6-TIF4631 $\Delta 1-186 / \Delta 844-952$. The mutant carrying the combined double $\mathrm{N}$-terminal and $\mathrm{C}$-terminal deletion and the replacement of 12 arginine residues by alanine in the central RNA-binding domain of pGEX6-TIF4631 was obtained with two partially complementary oligonucleotides: 5'-AATAG ATCTGCAGATTCTGGCGCATTCGGCAATAATTCTAGTGCAG GCCATGACTTTGCAAATACCTCAGTGGCAAATATGGATGAC GC-3' and 5'-ATAAGATCTATTAGATGCCGCGTCATTCATT GCCTTTGATGCTGCCTTTGATGAAGTTGCTGAATTAGCTGC GTCATCCATATTTGCC-3'. An 18-bp duplex was formed after annealing of the $3^{\prime}$ ends of both oligonucleotides. Single-strand regions were filled in with T4 DNA polymerase and dNTPs and a 162-bp double-stranded DNA fragment obtained (the corresponding arginine residues of Tif4631p located at positions 493, 497, $504,509,514,519,523,528,529,532,537$, and 538 were replaced by alanines) that was digested with BglII and inserted in the correct orientation in pGEX6-TIF4631 $\Delta 1-186 / \Delta 493-543 / \Delta 844-952$. The construct was called pGEX6-TIF4631 $\Delta 1 \mathrm{~m} 2 \Delta 3$.

For expression in yeast cells, constructs were subcloned as $B a m H I-E c o R I$ or EcoRI fragments into the unique sites of the vectors p301 (TRP1 gene as selectable marker; GAL1/10 promoter) and pRS313 (HIS3 gene as selectable marker; Sikorski and Hieter 1989) carrying the complete 5' UTR of TIF4631 from bp -522 to +1 (Goyer et al. 1993). For expression in E. coli, the constructs were introduced into pGEX-6P-2 for production of GST fusion proteins and eIF4G1 proteins coexpressed with eIF4E (from a pT74E-derivative plasmid conferring kanamycin-resistance; Edery et al. 1988).

\section{Growth of E. coli strains}

E. coli strains carrying pGEX plasmids were grown in LB medium (bacto-tryptone 1\%, $\mathrm{NaCl} 1 \%$, yeast extract $0.5 \%, 50 \mu \mathrm{g} / \mathrm{mL}$ ampicillin, $30 \mu \mathrm{g} / \mathrm{mL}$ chloramphenicol) overnight at $37^{\circ} \mathrm{C}$, diluted 1:50 into $1 \mathrm{~L}$ of fresh $\mathrm{LB}$ medium, grown at $37^{\circ} \mathrm{C}$ until the $\mathrm{A}_{600}$ reached $0.5-1$ and the expression of fusion proteins induced with $0.5-1 \mathrm{mM}$ isopropyl $\beta$-D-thiogalactoside for $4 \mathrm{~h}$. Cells were harvested and resuspended in $15 \mathrm{~mL}$ of ice-cold phosphate-buffered saline (PBS; $10 \mathrm{mM} \mathrm{Na} \mathrm{HPO}_{4}, 1.8 \mathrm{mM} \mathrm{KH}_{2} \mathrm{PO}_{4}$ at $\mathrm{pH} 7.3,140$ $\mathrm{mM} \mathrm{NaCl}, 2.7 \mathrm{mM} \mathrm{KCl}$ ) or in TBS/ $\mathrm{NaCl} /$ Triton $(10 \mathrm{mM}$ Tris- $\mathrm{HCl}$ at $\mathrm{pH} 7.5,650 \mathrm{mM} \mathrm{NaCl}, 0.2 \%$ Triton X-100) and lysed with a French Press at $1000 \mathrm{psi}$. The suspension was centrifuged at $7650 \mathrm{~g}$ for $15 \mathrm{~min}$ at $4^{\circ} \mathrm{C}$.

\section{Protein purification}

GSH-Sepharose affinity chromatography

Fifteen milliliters of cleared lysate were incubated with $0.5 \mathrm{~mL}$ glutathione (GSH) Sepharose 4B (Amersham Pharmacia Biotech;
0.25-mL slurry equilibrated with TBS) with gentle agitation for 4 h to overnight at $8^{\circ} \mathrm{C}$. After centrifugation at $350 \mathrm{~g}$ for $5 \mathrm{~min}$, the unbound fraction was disposed. The slurry was washed with 15 mL TBS, transferred to an Eppendorf tube, and washed twice with $1 \mathrm{~mL}$ TBS. Then the slurry was incubated with $0.5 \mathrm{~mL}$ GSH elution buffer (100 mM Tris- $\mathrm{HCl}$ at $\mathrm{pH} 9.0,120 \mathrm{mM} \mathrm{NaCl}, 10 \mathrm{mM} \mathrm{GSH}$, adjusted to $\mathrm{pH} 9$ ) for $30 \mathrm{~min}$ at $8^{\circ} \mathrm{C}$, centrifuged for $5 \mathrm{~min}$ at $350 \mathrm{~g}$, and the proteins collected from the supernatant. When GST fusion proteins were used for RNA binding or in vitro translation experiments after this step, they were dialyzed against buffer B (20 $\mathrm{mM}$ HEPES at $\mathrm{pH} 7.4,1 \mathrm{mM} \mathrm{MgCl}_{2}, 100 \mathrm{mM} \mathrm{KCl}$ ) and, when necessary, concentrated by Centricon centrifugation (Amicon). Glycerol (10\% final concentration) and $\beta$-mercaptoethanol (7 $\mathrm{mM}$ final concentration) were added, and aliquots were frozen in liquid nitrogen and kept at $-70^{\circ} \mathrm{C}$.

\section{Ni-chelate affinity chromatography}

For the purification of double-tagged eIF4G1 $1_{1-952}$ carrying GST at the $\mathrm{N}$ terminus and six histidine residues at the $\mathrm{C}$ terminus, the cleared lysates were first incubated with glutathione Sepharose 4B and eIF4G1 $1_{1-952}$ isolated as described above. The GSH eluates were combined and $\mathrm{LiCl}$ was added to a final concentration of 0.3 M. The eluate was then incubated with $30 \mathrm{~mL}$ Ni-NTA Agarose (Qiagen) overnight at $8^{\circ} \mathrm{C}$, centrifuged at $350 \mathrm{~g}$ for $5 \mathrm{~min}$, and washed three times with $1 \mathrm{~mL}$ TBS. The protein was eluted in two steps at $8^{\circ} \mathrm{C}$ with $80 \mathrm{~mL} 250 \mathrm{mM}$ imidazole (in TBS) for $2 \mathrm{~h}$. The eluates were combined and dialyzed against buffer B $(20 \mathrm{mM}$ HEPES- $\mathrm{KOH}$ at $\mathrm{pH} 7.4,1 \mathrm{mM} \mathrm{MgCl}_{2}, 100 \mathrm{mM} \mathrm{KCl}$ ) and frozen in $10 \%$ glycerol at $-70^{\circ} \mathrm{C}$.

\section{DEAE treatment}

Approximately $0.5 \mathrm{~mL}$ of DEAE resin were washed with $10 \mathrm{~mL}$ $\mathrm{ddH}_{2} \mathrm{O}$, mixed with protein diluted 1:10 with buffer A $(30 \mathrm{mM}$ HEPES-KOH at pH 7.4, $100 \mathrm{mMKAc}_{2}, 2 \mathrm{mM} \mathrm{MgAc}_{2}$ ), and incubated with the DEAE matrix for $30 \mathrm{~min}$ at $8^{\circ} \mathrm{C}$ on a shaker. After centrifugation at $350 \mathrm{~g}$ for $5 \mathrm{~min}$, the proteins were collected from the supernatant.

\section{Gel filtration}

Proteins were purified by gel filtration on a Superdex S75 (16/60) column (Pharmacia) in FPLC buffer $(20 \mathrm{mM}$ Tris- $\mathrm{HCl}$ at $\mathrm{pH} 7.5$, $100 \mathrm{mM} \mathrm{NaCl}, 1 \mathrm{mM}$ EDTA, $0.005 \% \mathrm{NaN}_{3}$ ). Fractions containing the proteins were identified by SDS-polyacrylamide gel electrophoresis and pooled. The pooled fractions were dialyzed against buffer A, when necessary concentrated by Centricon centrifugation (Amicon), and kept in $10 \%$ glycerol at $-70^{\circ} \mathrm{C}$ or at $-20^{\circ} \mathrm{C}$.

\section{Polyacrylamide gel electrophoresis and Western blot analysis}

Proteins were fractionated on 15\% SDS-polyacrylamide gels (Anderson et al. 1973) and stained with Coomassie blue R-250. Western blotting was done as described (Berset et al. 1998).

\section{Protein concentration determination}

The concentrations of eIF4G1 $1_{1-82}$ and eIF4G1 $1_{883-952}$ were measured by absorbance spectrometry. The concentrations of other protein preparations were measured with the Bradford assay or 
estimated on gels stained with Coomassie blue using bovine serum albumin (BSA) as standard. Dilutions of protein preparations were prepared in buffer B containing $20 \mu \mathrm{g} / \mathrm{mL}$ BSA.

\section{RNA labeling}

One-hundred picomoles of synthetic RNA $\left(5^{\prime}\right.$-(AAAAC) 4 AAAAUAGCACCGUAAAGC-3', 38 nt; all synthetic RNA oligonucleotides were obtained from W.C. Merrick) were labeled with 10 units T4 polynucleotide kinase (PNK) in PNK buffer $(50 \mathrm{mM}$ Tris- $\mathrm{HCl}$ at $\mathrm{pH} 8.2,10 \mathrm{mM} \mathrm{MgCl}_{2}, 0.1 \mathrm{mM}$ EDTA, $5 \mathrm{mM}$ dithiothreitol, $0.1 \mathrm{mM}$ spermidine $)$ and 10 pmole $\left[\gamma_{-}{ }^{32} \mathrm{P}\right]$-ATP $(\approx 30$ $\mu \mathrm{Ci})$. This reaction mixture was incubated for $30 \mathrm{~min}$ at $37^{\circ} \mathrm{C}$. Subsequently, phenol/chloroform extraction and ethanol precipitation were carried out and the labeled RNA was purified on a G25-Sepharose column to remove unincorporated $\left[\gamma^{-}{ }^{32} \mathrm{P}\right]$-ATP. The specific activity of the labeled RNA was about $0.3 \mu \mathrm{Ci} /$ pmole RNA.

\section{Filter-binding assay}

Two-hundred-fifty to 300 fmole $(12.5 \mathrm{nM}$ to $15 \mathrm{nM}$ final concentration) of $\left[{ }^{32} \mathrm{P}\right]-\mathrm{RNA}$ was incubated with eIF4G1 in a $20-\mu \mathrm{L}$ reaction mixture containing buffer $\mathrm{A}$. The binding partners were incubated for $2 \mathrm{~min}$ at $0^{\circ} \mathrm{C}$ and filtered through a nitrocellulose filter (type HA $0.45 \mu \mathrm{m}$; Millipore) prewetted with $35 \mu \mathrm{L}$ buffer A. The filters were washed with $600 \mu \mathrm{L}$ buffer A, dried, and counted in 3-mL scintillation cocktail (IRGA-SAFE PLUS, Packard). Triple values for each protein concentration were measured. The $K_{\text {Dapprox }}$ was calculated according to the formula $K_{D}=\left([\text { protein }]_{\text {free }}\right.$. $\left.[\mathrm{RNA}]_{\text {free }}\right) /[$ complex $]$, where $[\text { protein }]_{\text {free }}$ corresponds to $[\text { protein }]_{\text {tot }}$ - [complex $],[\mathrm{RNA}]_{\text {free }}$ corresponds to $[\mathrm{RNA}]_{\text {tot }}-[$ complex $]$, and [complex] corresponds to $[\mathrm{RNA}]_{\text {tot }} \cdot$ bound cpm on the filter/total cpm input (total RNA).

Optimal conditions for RNA binding in our filter-binding assay were tested: eIF4G1 $1_{492-539}$, eIF4G1 $1_{883-952}$, and eIF4G1 $1_{1-952}$ bound similar amounts of RNA at $0^{\circ} \mathrm{C}$ and at $37^{\circ} \mathrm{C}$ after $10 \mathrm{~min}$ of incubation. The concentration of $\mathrm{KCl}(0 \mathrm{mM}, 50 \mathrm{mM}$, or 100 $\mathrm{mM}$ ) in the buffer had little or no influence on the amount of RNA bound. The kinetics of RNA binding were fast, as there was no significant change in binding between $1,3,5$, and $10 \mathrm{~min}$ of incubation at $0^{\circ} \mathrm{C}$.

The integrity of RNA after incubation with the different proteins was checked by fractionation of the reaction mixtures on a $12 \%$ denaturing polyacrylamide gel (12\% acrylamide/bisacrylamide, 19:1, 40\% urea) in $90 \mathrm{mM}$ Tris-borate ( $\mathrm{pH} 8.0$ ), $2 \mathrm{mM}$ EDTA. The gel was dried and exposed to an X-ray film.

\section{Protein binding to poly $(\mathrm{U})$}

Forty milligrams of poly(U)-agarose (dried; from Sigma) were

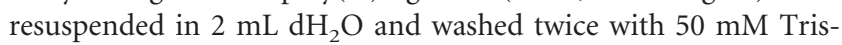
$\mathrm{HCl}$ ( $\mathrm{pH}$ 7.5), $50 \mathrm{mM} \mathrm{NaCl}$. One hundred microliters of poly(U)agarose suspension were incubated with about $1 \mu \mathrm{g}$ of eIF4G1 proteins (100-200 ng of full-length eIF4G1) on ice for $1 \mathrm{~h}$. Where indicated, incubation was done in the presence of $200 \mu \mathrm{g} / \mathrm{mL}$ poly $(\mathrm{U})$ (Sigma). After incubation, the resin was washed three times with $200 \mu \mathrm{L}$ of $50 \mathrm{mM}$ Tris- $\mathrm{HCl}$ at $\mathrm{pH}$ 7.5, $50 \mathrm{mM} \mathrm{NaCl}$, and bound protein was eluted by boiling for $1 \mathrm{~min}$ in $10 \mu \mathrm{L}$ SDS sample buffer.

\section{Phenotype of elF4G1 RNA-binding mutants}

The plasmids carrying the eIF4G1 mutants were transformed into yeast strain CBY19 (tif4631::LEU2 tif4632::ura3 〈YCp50TIF4631; URA3〉; Berset et al. 1998). CBY19 transformants were plated on fluoro-orotic acid (FOA) plates containing $0.7 \%$ FOA to eliminate the plasmid expressing wild-type eIF4G. CBY19 transformants that had lost the URA3 plasmid were grown at $25^{\circ}, 30^{\circ}$, and $37^{\circ} \mathrm{C}$ to analyze for a temperature- or cold-sensitive phenotype.

\section{Cell-free translation}

Preparation of yeast translation systems and translation reactions were done according to Blum et al. (1989) using the eIF4G-dependent yeast extract described by Dominguez et al. (2001).

\section{ACKNOWLEDGMENTS}

We thank Elisabeth Kislig and Sandra Nansoz for excellent technical assistance. This work was supported by grant 31-45528.95 of the Swiss National Science Foundation and a grant to C.B. from the Novartis Foundation, Basel, Switzerland.

The publication costs of this article were defrayed in part by payment of page charges. This article must therefore be hereby marked "advertisement" in accordance with 18 USC section 1734 solely to indicate this fact.

Received February 25, 2003; accepted March 28, 2003.

\section{REFERENCES}

Altmann, M., Schmitz, N., Berset, C., and Trachsel H. 1997. A novel inhibitor of cap-dependent translation initiation in yeast: p20 competes with eIF4G for binding to eIF4E. EMBO J. 16: 11141121.

Anderson, C.W., Baum, P.R., and Gesteland, R.F. 1973. Processing of adenovirus 2-induced proteins. J. Virol. 12: 241-252.

Berset, C., Trachsel, H., and Altmann, M. 1998. The TOR (target of rapamycin) signal transduction pathway regulates the stability of translation initiation factor eIF4G in the yeast Saccharomyces cerevisiae. Proc. Natl. Acad. Sci. 95: 4264-4269.

Birney, E., Kumar, S., and Krainer, A.R. 1993. Analysis of the RNArecognition motif and RS and RGG domains: Conservation in metazoan pre-mRNA splicing factors. Nucleic Acids Res. 21: 58035816.

Blum, S., Mueller, M., Schmid, S.R., Linder, P., and Trachsel, H. 1989. Translation in Saccharomyces cerevisiae: Initiation factor 4A-dependent cell-free system. Proc. Natl. Acad. Sci. 86: 6043-6046.

Burd, C.G. and Dreyfuss, G. 1994. Conserved structures and diversity of functions of RNA-binding proteins. Science 265: 615-621.

Dever, T.E. 2002. Gene-specific regulation by general translation factors. Cell 108: 545-556.

Dominguez, D., Altmann, M., Benz, J., Baumann, U., and Trachsel, H. 1999. Interaction of translation initiation factor eIF4G with eIF4A in the yeast Saccharomyces cerevisiae. J. Biol. Chem. 274: 2672026726.

Dominguez, D., Kislig, E., Altmann, M., and Trachsel, H. 2001. Structural and functional similarities between the central eukaryotic 
initiation factor (eIF)4A-binding domain of mammalian eIF4G and the eIF4A-binding domain of yeast eIF4G. Biochem J. 355: 223-230.

Edery, I., Altmann, M., and Sonenberg, N. 1988. High-level synthesis in Escherichia coli of functional cap-binding eukaryotic initiation factor eIF-4E and affinity purification using a simplified cap-ana$\log$ resin. Gene 74: 517-525.

Ghisolfi, L., Joseph, G., Amalric, F., and Erard M. 1992. The glycinerich domain of nucleolin has an unusual supersecondary structure responsible for its RNA-helix-destabilizing properties. J. Biol. Chem. 267: 2955-2959.

Gingras, A.C., Raught, B., and Sonenberg, N. 1999. eIF4 initiation factors: Effectors of mRNA recruitment to ribosomes and regulators of translation. Annu. Rev. Biochem. 68: 913-963.

- 2001. Regulation of translation initiation by FRAP/mTOR. Genes \& Dev. 15: 807-826.

Goyer, C., Altmann, M., Lee, H.S., Blanc, A., Deshmukh, M., Woolford, J.L., Trachsel, H., and Sonenberg, N. 1993. TIF4631 and TIF4632-Two yeast genes encoding the high-molecular-weight subunits of the cap-binding protein complex (eukaryotic initiation factor-4F) contain an RNA recognition motif-like sequence and carry out an essential function. Mol. Cell. Biol. 13: 4860-4874.

Gradi, A., Imataka, H., Svitkin, Y.V., Rom, E., Raught, B., Morino, S., and Sonenberg, N. 1998. A novel functional human eukaryotic translation initiation factor 4G. Mol. Cell. Biol. 18: 334-342.

Henikoff, S. 1987. Unidirectional digestion with exonuclease III in DNA sequence analysis. Methods Enzymol. 155: 156-165.

Henikoff, S. 1990. Ordered deletions for DNA sequencing and in vitro mutagenesis by polymerase extension and exonuclease III gapping of circular templates. Nucleic Acids Res. 18: 2961-2966.

Hentze, M.W. 1997. eIF4G: A multipurpose ribosome adapter? Science 275: 500-501.

Hershey, J.W.B. and Merrick, W.C. 2000. Pathway and mechanism of initiation of protein synthesis. In Translational control of gene expression (eds. N. Sonenberg et al.), pp. 615-635. Cold Spring Harbor Laboratory Press, Cold Spring Harbor, NY.

Imataka, H. and Sonenberg, N. 1997. Human eukaryotic translation initiation factor $4 \mathrm{G}$ (eIF4G) possesses two separate and independent binding sites for eIF4A. Mol. Cell. Biol. 17: 6940-6947.

Imataka, H., Gradi, A., and Sonenberg. N. 1998. A newly identified $\mathrm{N}$-terminal amino acid sequence of human eIF4G binds poly(A)binding protein and functions in poly $(\mathrm{A})$-dependent translation. EMBO J. 17: 7480-7489.

Kiledjian, M. and Dreyfuss, G. 1992. Primary structure and binding activity of the hnRNP U protein: Binding RNA through RGG box. EMBO J. 11: 2655-2664.

Kim, C.Y., Takahashi, K., Nguyen, T.B., Roberts, J.K., and Webster, C. 1999. Identification of a nucleic acid binding domain in eukaryotic initiation factor eIFiso4G from wheat. J. Biol. Chem. 274: 1060310608.

Kozak, M. 1989. The scanning model for translation: an update. J. Cell.
Biol. 108: 229-241.

Lamphear, B.J., Kirchweger, R., Skern, T., and Rhoads, R.E. 1995. Mapping of functional domains in eukaryotic protein synthesis initiation factor 4G (eIF4G) with picornaviral proteases-Implications for cap-dependent and cap-independent translational initiation. J. Biol. Chem. 270: 21975-21983.

Lanker, S., Müller, P.P., Altmann, M., Goyer, C., Sonenberg, N., and Trachsel, H. 1992. Interactions of the eIF-4F Subunits in the Yeast Saccharomyces cerevisiae. J. Biol. Chem. 267: 21167-21171.

Lomakin, I.B., Hellen, C.U., and Pestova, T.V. 2000. Physical association of eukaryotic initiation factor $4 \mathrm{G}$ (eIF4G) with eIF4A strongly enhances binding of eIF4G to the internal ribosomal entry site of encephalomyocarditis virus and is required for internal initiation of translation. Mol. Cell. Biol. 20: 6019-6029.

Mader, S., Lee, H., Pause, A., and Sonenberg, N. 1995. The translation initiation factor eIF-4E binds to a common motif shared by the translation factor eIF-4 gamma and the translational repressors 4E-binding proteins. Mol. Cell. Biol. 15: 4990-4997.

Marcotrigiano, J., Lomakin, I.B., Sonenberg, N., Pestova, T.V., Hellen, C.U., and Burley, S.K. 2001. A conserved HEAT domain within eIF4G directs assembly of the translation initiation machinery. Mol. Cell 7: 193-203.

Morley, S.J., Curtis, P.S., and Pain, V.M. 1997. eIF4G: Translation's mystery factor begins to yield its secrets. RNA 3: 1085-1104.

Neff, C.L. and Sachs, A.B. 1999. Eukaryotic translation initiation factors $4 \mathrm{G}$ and $4 \mathrm{~A}$ from Saccharomyces cerevisiae interact physically and functionally. Mol. Cell. Biol. 19: 5557-5564.

Pain, V.M. 1996. Initiation of protein synthesis in eukaryotic cells. Eur. J. Biochem. 236: 747-771.

Pestova, T.V., Hellen, C.U., and Shatsky, I.N. 1996. Canonical eukaryotic initiation factors determine initiation of translation by internal ribosomal entry. Mol. Cell. Biol. 16: 6859-6869.

Pyronnet, S., Imataka, H., Gingras, A.C., Fukunaga, R., Hunter, T., and Sonenberg, N. 1999. Human eukaryotic translation initiation factor $4 \mathrm{G}(\mathrm{eIF} 4 \mathrm{G})$ recruits Mnk1 to phosphorylate eIF4E. EMBO J. 18: $270-279$.

Sachs, A.B., Sarnow, P., and Hentze, M.W. 1997. Starting at the beginning, middle, and end: Translation initiation in eukaryotes. Cell 89: $831-838$.

Saxena, P. and Walker, J.R. 1992. Expression of argU, the Escherichia coli gene coding for a rare arginine tRNA. J. Bacteriol. 174: 19561964.

Sikorski, R.S. and Hieter, P. 1989. A system of shuttle vectors and yeast host strains designed for efficient manipulation of DNA in Saccharomyces cerevisiae. Genetics 122: 19-27.

Tarun, S.J. and Sachs, A.B. 1996. Association of the yeast poly(A) tail binding protein with translation initiation factor eIF-4G. EMBO J. 15: 7168-7177.

Yan, R.Q., Rychlik, W., Etchison, D., and Rhoads R.E. 1992. Amino acid sequence of the human protein synthesis initiation factor-eIF4gamma. J. Biol. Chem. 267: 23226-23231. 

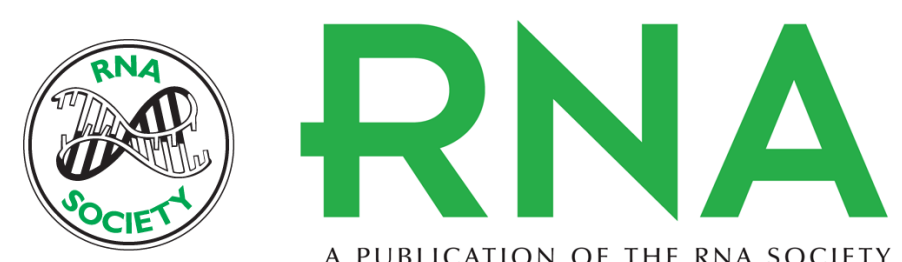

A PUBLICATION OF THE RNA SOCIETY

\section{RNA-binding activity of translation initiation factor elF4G1 from Saccharomyces cerevisiae}

CATHERINE BERSET, ANDREAS ZURBRIGGEN, SIAMAK DJAFARZADEH, et al.

RNA 2003 9: 871-880

References This article cites 38 articles, 24 of which can be accessed free at: http://rnajournal.cshlp.org/content/9/7/871.full.html\#ref-list-1

License

Email Alerting Receive free email alerts when new articles cite this article - sign up in the box at Service the top right corner of the article or click here.

To subscribe to RNA go to:

http://rnajournal.cshlp.org/subscriptions 